\title{
Putusan Munas Muhammadiyah Mengenai Koreksi Ketinggian Matahari Subuh dalam Fikih dan Astronomi
}

\section{Risma Cahyani}

Institut Agama Islam Negeri Ponorogo rismacahya199@gmail.com

Abstract: in syar'i prayer is an obligator for every muslim whose time has been determined. In determining the initial prayer time, the position of the sun is the main factor that must be considered, as a result every different day and different place, the prayer time will also be different. This difference was also found in the initial determination of the time for the dawn prayer, majelis tarjih an tajdid muhammadiyah in december 2020 in the decision of the nastional conference which was also held by tahfidz in march 2021, correcting the height of the dawn sun which was originally -200 corrected to 180 below the horizon. The consequence of this decision was that the dawn time for muhammadiyah was delayed by about 8 minutes from the dawn time schedule set by the ministry of religion. This raises a bit of polemic for same muslims because the dawn preyer is an activity that also includes two acts of worship, namely fasting and prayer. So if a question is drawn, what if some who is still in a state of sahur then hears that the time for the call to adzan has arrived, then whether his fast can be continued or not. This can be studied in more dept from the prespective of fikih and astronomy.

Keywords: Decision of Majelis Tarjih Muhammadiyah Council, Sun Height, Dawn.

Abstrak: Secara syar'i sholat merupakan kewajiban bagi setiap muslim yang telah ditentukan waktunya. Dalam penetapan awal waktu shalat posisi matahari adalah faktor utama yang harus 
diperhatikan, akibatnya setiap beda hari dan beda tempat, maka waktu shalat juga akan berbeda pula. Perbedaan tersebut juga didapati dalam penetapan awal waktu shalat subuh, Majlis Tarjih dan Tajdid Muhammadiyah pada bulan desember 2020 dalam putusan munasnya yang telah juga ditanhfidz pada bulan Maret 2021 mengoreksi ketinggian matahari subuh yang awalnya -20 derajat dikoreksi menjadi -18 derajat dibawah ufuk. Konsekuensi dari putusan tersebut waktu subuh untuk Muhammmadiyah mundur sekitar 8 menit dari jadwal waktu subuh yang telah ditetapkan oleh Kementrian Agama. Hal ini menimbulkan sedikit polemik bagi sebagian umat muslim karena sholat subuh merupakan kegiatan yang juga mencakup dua ibadah, yakni puasa dan shalat. Sehingga jika ditarik sebuah pertanyaan bagaimana jika seseorang yang masih dalam keadaan sahur kemudian mendengar waktu adzan telah tiba, lantas apakah puasanya dapat dilanjutkan atau tidak. Hal ini dapat dikaji lebih mendalam berdasarkan kacamata fikih dan juga astronomi.

Kata Kunci: Putusan Tarjih Muhammadiyah, Ketinggian Matahari, Waktu subuh.

\section{PENDAHULUAN}

Penentuan awal waktu shalat merupakan bagian dari ilmu falak yang perhitungannya ditetapkan berdasarkan garis edar matahari atau penelitian posisi matahari terhadap bumi. Secara syar'i shalat wajib (shalat maktubah) memiliki waktu yang telah ditentukan, sehingga didefinisikan sebagai ibadah muwaqqat. ${ }^{1}$ Oleh karena itu, menghisab waktu shalat pada dasarnya adalah menghitung kapan matahari akan menempati posisi tertentu yang sekaligus menjadi penunjuk waktu shalat, yaitu pada saat tergelincir, saat membuat

${ }^{1}$ Imroatul Munfarida, "Problematika dan Solusi tentang Penentuan Waktu Shalat dan Puasa di Daerah Abnormal (Kutub)" Journal Al-Syakhsiyyah Journal of Law and Family Studies, Vol. 3 No. 1 (Juni, 2021), 39. 
bayang-bayang sama panjang dengan bendanya, saat terbenam, saat hilangnya mega merah, saat terbitnya fajar dan saat terbit. Sehubungan dengan itu, saat matahari berkulminasi (mencapai titik puncak) seringkali juga dijadikan pedoman dalam menghisab setiap awal atau akhir shalat. ${ }^{2}$

Di Indonesia sendiri terdapat beberapa ulama yang mengemukakan pendapatnya mengenai ketinggian matahari pada waktu subuh, selain kriteria $-18^{0}$ ada ulama yang menilai besaran matahari waktu subuh sebesar $-19^{0}$ seperti Selamet Hambali dan Muhammad Ma'sum bin Ali, juga $-20^{\circ}$ yang dikemukakan oleh Abdur Rachim, Noor Ahmad SS, Muhyidin Khazin dan Arwin Juli Rakhmadi butar-butar. Hingga saat ini nilai yang disepakati adalah 20 derajat yang digunakan oleh Kementrian Agama sebagai pedoman dalam menentukan jadwal waktu shalat subuh bagi umat muslim Indonesia. ${ }^{3} \mathrm{Hal}$ ini menunjukkan bahwa ketinggian matahari dalam menentukan awal waktu shalat subuh dapat berbeda-beda karena adanya beberapa faktor seperti ketinggian tempat, polusi cahaya, keadaan alam, lintang tempat dan beberapa faktor lainnya. mengenai nilai besaran matahari untuk waktu subuh, telah disepakati di Indonesia dalam hal ini Kementrian Agama menggunakan $-20^{\circ}$, namun belakangan ini terdapat perbincangan yang cukup problematis mengenai keakuratan -20 derajat waktu subuh yang perlu untuk dikaji kembali. Hal ini disampaikan oleh salah satu ormas besar di Indonesia yaitu Majlis Tarjih dan Tajdid Muhammadiyah yang mengoreksi ketinggian matahari, yakni dari 20 derajat dikoreksi menjadi -18 derajat berdasarkan hasil Musyawarah Nasional (Munas) ke-31 pada bulan Desember 2020 lalu. Berdasarkan munas tersebut Muhammadiyah menyimpulkan bahwa angka $-20^{0}$ perlu dikoreksi dan menilai $-18^{0}$ merupakan angka yang lebih akurat, perubahan tersebut didasarkan pada

2 Encup Supriatna, Hisab Rukyat E Implikasinya (Bandung: Refika Aditama, 2007),

\section{${ }^{3}$ Ibid.,94}


penelitian dan hitungan astronomi yang dilakukan oleh beberapa pusat lembaga falak dari muhammadiyah yang mengamati perubahan cahaya di Indonesia selama beberapa tahun belakangan. 4 Dari permasalahan disini kita dapat mengkaji mengenai dasar/alasan Lembaga Tarjih mengoreksi waktu subuh, implikasinya serta pendapat beberapa fuqoha yang banyak mengeluarkan argumen mengenai ketinggian matahari pada waktu subuh.

\section{PEMBAHASAN}

\section{Hisab Awal Waktu Shalat Subuh dalam Fiqh Dan Astronomi 1 Waktu Shalat Subuh Perspektif Fiqh}

Shalat merupakan media ibadah bagi orang-orang yang beriman untuk beinteraksi secara langsung dengan Tuhannya yang telah ditentukan waktu-waktunya (surat An-Nisa: 103). Maka menurut para ulama bahwa shalat merupakan kewajiban yang harus dilaksanakan pada batas-batas waktu yang telah ditentukan, sehingga shalat termasuk ibadah muwaqqat, yaitu ibadah yang telah ditentukan waktu-waktunya. Shalat diwajibkan bagi umat islam dalam sehari semalam sebanyak lima (5) kali, yaitu Subuh, Dzuhur, Asyar, Magrib dan Isya. Dalam firman Allah di dalam Alquran telah ditentukan waktunya dalam ayat berikut:

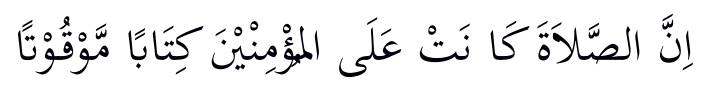

"Sesungguhnya shalat itu adalah fardhu yang ditentukan waktunya atas orang-orang yang beriman."

Dalam pandangan fikih waktu shalat subuh menurut fukoha sebagai berikut :

a Pendapat Madzab Hanafi

Dalam kitab al-Mabsuth dijelaskan tentang pendapat madzab hanafi dimana beliau berpendapat waktu shalat subuh dimulai sejak terbit fajar hingga terbitnya matahari. Menurut beliau fajar

${ }^{4}$ CNN Indonesia.com (diakses tanggal 27 Desember 2020) 
ada dua macam, yaitu fajar Kadzib dan fajar shadiq. Kemudian fajar kadzib belum (dianggap) masuk waktu shalat dan tidak dilarang untuk makan minum bagi orang yang hendak berpuasa.

b Pendapat Madzab Maliki

Dalam kitab Mawahib al-Jalil fi Syarhi Mukhtasar Syaikh Khalil dijelaskan bahwa fajar (sholat subuh) wajib dilaksanakan sejak terbit fajar kedua yaitu fajar shadiq hingga waktu siang. Jika waktu isfar (sinar terang sebelum matahari muncul) habislah waktu ihtiyar dan tidak boleh menunda shalat bagi orang yang tidak ada udzur sampai terbit matahari.

c Pendapat Madzab Syafi'i

Dalam kitab al-Umm dijelaskan apabila fajar yang terakhir (fajar Shadiq) sudah terlihat jelas maka sah untuk shalat subuh. Imam Syafi'i mendasarkan pendapatnya tersebut sebagaimana pendapat mayoritas ahli fikih dimulai sejak terbit fajar shadiq dan berakhir menjelang terbitnya matahari.

d Pendapat Madzab Hambali

Ibnu Quddamah dalam al-Mughni menjelaskan pendapat madzab hambali, menurutnya apabila telah terbit fajar yang kedua wajib melaksanakan sholat subuh dan waktunya berakhir menjelang terbitnya matahari. Fajar shadiq memberikan kepastian tentang tibanya waktu subuh hingga waktu ihtiyar yaitu hingga tibanya waktu isfar, sedangkan waktu setelahnya disebut waktu dharurat sampai terbit matahari. ${ }^{5}$

\section{Waktu Shalat Subuh Perspktif Astronomi}

Dalam kajian kelimuan falak, waktu-waktu shalat kemudian diperinci dari sebuah dasar Alquran dan Hadits nabi Muhammad menjadi sebuah pemahaman teks dengan konteks dari hasil kolaborasi pemahaman perspektif fikih dan keilmuan modrn astronomi serta geografi kemudian didefinisikan melalui sebuah

5 Ruslan fariadi, waktu subuh perspektif hadits dan madzab, suara muhammadiyah dalam http://suaramuhammadiyah.id/2021/05/17/waktu-subuh-perspektif-haditsdan-madzab/?nv4dietuy=yamp 
perhitungan sebagai patokan waktu bagi umat Islam untuk menjalankan ibadah shalat tepat waktunya. 6

Untuk menentukan waktu shalat lima waktu, ada beberapa parameter yang mesti diketahui: pertama, koordinat lintang (Lt) bagi daerah yang terletak di sebelah utara garis khatulistiwa memiliki lintang posistif $(+)$ sedangkan yang berada disebelah selatan memiliki lintang negatif (-). Kedua adalah koordinat bujur tempat (Bt), dengan ketentuan daerah yang terletak di sebelah timur Greenwich bujur bernilai positif, sedangkan di sebelah barat Greenwich bujur bernilai negatif. Ketiga, memperhitungkan zona waktu tempat (Z) dengan ketentuan bagi daerah yang terletak di sebelah timur Greenwich memiliki Z posistif. Keempat, ketinggian lokasi lokasi daerah dari permukaan laut $(\mathrm{H})$. Kelima, menentukan tanggal $(\mathrm{D}=$ date), bulan ( $\mathrm{M}=$ month), dan tahun ( $\mathrm{Y}=$ year) kalender Gregorian. Tanggal, bulan dan tahun menjadi parameter karena penentuan waktu shalat pada tanggal tersebut. Selanjutnya dihitung nilai Julian Day (JD). Keenam Sudut Deklinasi Matahari (Delta). Ketujuh, Equator Of Time (ET). Kedelapan, Altitude/ketinggian matahari waktu shalat subuh, asyar dan isya'. ${ }^{\prime}$ Secara umum waktu shalat subuh astronomi adalah dimulai saat mulai meredupnya cahaya bintang-bintang dimana ketinggian matahari saat itu berada 18 derajat dibawah ufuk atau ketika munculnya fajar yang disebut sebagai astronomi/astronomical twilight. ${ }^{8}$

\section{Fajar dalam Fikih dan Astronomi}

\section{Fajar dalam Fikih}

Beberapa dalil Alquran dan hadits menyebutkan bahwa waktu subuh adalah sejak terbitnya fajar shadiq hingga terbit matahari. Ulama sepakat, waktu subuh bermula ketika terbit fajar yang kedua

${ }^{6}$ Muhammad Hadi Bashori, Pengantar Ilmu Falak (Jakarta: Pustaka Al-Kautsar, 2015), 155

7 ibid, 156

8 Unggul, "Problematika Awal Waktu Subuh Antara Fikih dan Astronomi", AlAfaq: Desember 2020, 92 
(al-fajr ats-tsani) atau disebut fajar shadiq. Secara bahasa fajar (al-fajr) adalah pencahayaan gelap malam dari sinar pagi. Para ulama sepakat bahwa fajar ada dua yaitu fajar kadzib dan fajar shadiq. ${ }^{9}$

Dalam hadits yang diriwayatkan oleh Al-Hakim dan AlBaihaqi dari Ibn Abbas ra, bahwa Nabi Muhammad bersabda:

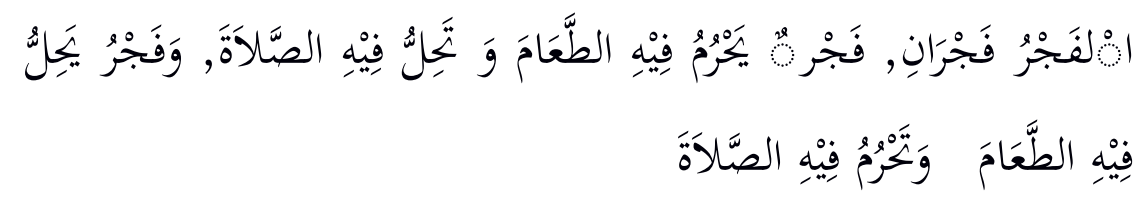

"fajar itu ada dua: (pertama) fajar yang didalamnya haram makanan serta dihalalkan shalat, (kedua) fajar yang didalamnya halal makanan dan haram shalat subuh". 10

Dalam sebuah riwayat disebutkan :

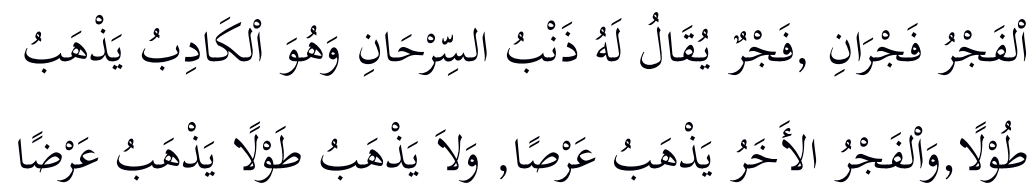

"fajar ada dua, fajar yang disebut seperti ekor serigala adalah fajar kadzib yang memanjang vertical dan tidak menyebar secara horizontal, yang kedua fajar yang melebar (horizontal)dan bukan vertical"'11

Fajar Kadzib (al-fajr al-kadzib) disebut dengan fajar pertama (alfajr al-awwal) karena muncul pertama kali dan berikutnya disusul munculnya fajar shadiq. Tanda tanda alami fajar kadzib adalah ia muncul menjulang ke langit laksana seekor serigala dan sesaat kemudian menghilang. Fajar kadzib adalah fajar yang bohong, sesuai

${ }^{9}$ Arwin Jazuli Rakhmadi Butar-Butar, Fajar Shafaq dalam Kesarjanaan Astronomi Muslim dan Ulama Nusantara (Yogyakarta: LKIS, 2018), 1

${ }^{10}$ Ahmad bin Husain bin Ali bin Musa Abu Bakar Al-Baihaqy, Sunan al-Baihaqy Al-Kubra, Makkah al-Mukarromah: Maktabah Dar al-Baz, 1994), juz 10, 707.

11 Al-imam Muhammad bin Ismail Al-Amirul Yamani Al-shin'ani, Subulus salam sarkh bulughul maram jilid 1 (Bairut: Dar Al-Fikr) terjm. Al-Albani dalam as-Shahihah no. 22 shahih al-jami: 4278 
namanya pada saat menjelang pagi, ada cahaya agak terang yang memanjang dan mengarah ke atas ditengah di langit. Bentuknya seperti ekor serigala kemudian langit menjadi gelap kembali. Fajar kadzib dalam bahasa inggris biasa dikenal dengan Twilight false atau Zodiacal Light. ${ }^{12}$

Sementara itu fajar shadiq (al fajr ash-shadiq) disebut juga fajar kedua (al fajr ats-tsany). Dinamakan demikian karena ia muncul setelah fajar kadzib. Tanda-tanda alami fajar shadiq adalah tampak menyebar di sepenjuru ufuk dengan warna keputih-putihan. Cahayanya terus bertambah sampai akhirnya terbit matahari. ${ }^{13}$ Menurut An-nawawi (w.676 H/1277 M) dinamakan fajar kadzib (dusta) adalah karena fajar ini pada awalnya tampak (muncul) dan bersinar namun kemudian menghilang. Sementara itu dinamakan fajar shadiq karena ia dikategorikan benar-benar tampak dan jelas, dan ia menjadi pertanda tiba dan dimulainya waktu subuh. ${ }^{14}$ Didalam Alquran istilah fajar disebut dengan dua istilah yaitu "alkhaith al-abyadh" (benang putih) sebagai fajar shadiq dan "al-khaith alaswad" (benang hitam) sebagai fajar kadzib. Dua istilah ini ditemukan dalam Q.S Al-Baqarah ayat 187 :

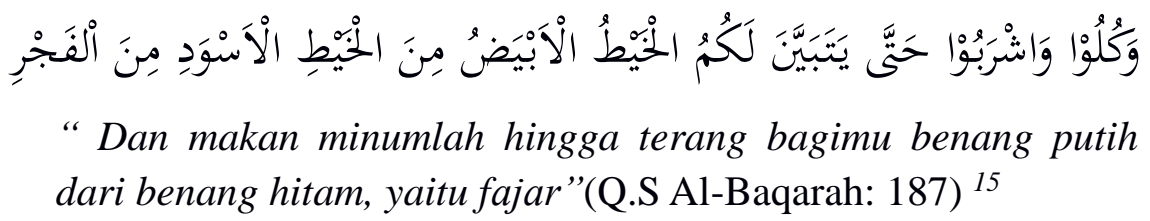

Benang putih (al-khaith al-abyadh) dalam ayat ini difahami sebagai batas dimulainya puasa yang mana ia muncul setelah munculnya benang hitam (al-khaith al-aswad).

12 Unggul, "Problematika Awal Waktu Subuh Antara Fikih dan Astronomi”, 90

13 Menurut Wahbah az-Zazuli fajar shadiq menjadi pertanda dimulainya awal subuh adalah cahaya putih yang nampak dan menyebar di ufuk timur yang muncul beberapa saat setelah fajar kadzib. Nusantara, 2.

14 Butar-Butar, Fajar Shafaq dalam Kesarjanaan Astronomi Muslim dan Ulama

${ }^{15}$ Kementrian Agama, Al-quran dan Terjemahan ( Bandung: PT Sygma Examedia Arkanleema, 2019), 29 


\section{Fajar dalam Astronomi}

Secara astronomis, sehubungan dengan posisi matahari saat subuh terdapat tiga jenis cahaya fajar (morning twiligh) yaitu : ${ }^{16}$

a Fajar astronomi/Falaky (dawn astronomical twilight) yaitu ketika matahari berada pada posisi $18^{0}$ sampai $12^{0}$ di bawah ufuk. Cahaya fajar ini sebagai pertanda akhir malam karena cahaya bintang mulai meredup akibat berhamburan cahaya matahari yang mulai muncul.

b Fajar Pelayaran/bahry (nautical twilight) yaitu ketika matahari berada pada posisi 12 hingga 6 dibawah ufuk. Cahaya fajar ini menampakkan ufuk atau kaki langit yang terlihat semakin jelas ketika berada di laut.

c Fajar sipil/madany (civil twilight) yaitu ketika matahari berada pada posisi 6 hingga 0 di bawah ufuk. Pada saat ini bendabenda ditempat terbuka sudah dapat terlihat mesli tanpa lampu penerangan.

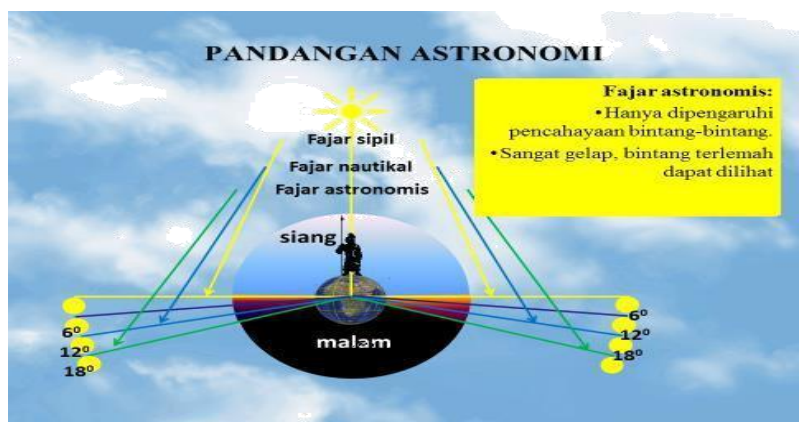

Astronomical twilight (fajar astronomi) inilah yang menurut ilmuan falak yaitu Slamet Hambali yang disebut fajar shadiq, dan dalam Ilmu falak dipahami sebagai awal cahaya yang mulai muncul di ufuk timur menjelang terbit matahari pada saat matahari berada sekitar $-18^{0}$ di bawah ufuk (atau jarak zenit matahari 108 derajat). Pendapat lain menyatakan bahwa terbitnya fajar shidiq dimulai pada saat posisi matahari $20^{\circ}$ dibawah ufuk (atau jarak zenit 110 derajat).

16 Unggul, "Problematika Awal Waktu Subuh Antara Fikih dan Astronomi”, 92 
Pada awal fajar astronomi ufuk tidak dapat di identifikasi lagi dalam arah manapun. Langit demikian redup, melebihi awal fajar nautika sehingga jika kondisinya memungkinkan, bintang paling redup yang bisa dilihat dengan mata telanjang (magnitudo smu +5 hingga +6 ) akan terlihat, dan berbeda dengan fajar nautika maupun fajar sipil, awal fajar astronomi hanya bisa dikenali di tempat yang betul-betul terbebas dari gangguan polusi cahaya dengan kondisi langit yang cerah tanpa gangguan cahaya bulan. Umumnya awal fajar astronomi terjadi saat tinggi matahari minus $18^{0}$ dari ufuk timur. ${ }^{17}$

Akar permasalahan awal waktu subuh adalah waktu, subuh, dan fajar. Waktu adalah doktrin yang sangat mendasar dalam kehidupan manusia. Begitu pentingnya waktu sehingga tidak ada hari tanpa waktu, tidak ada waktu tanpa ibadah, tidak ada ibadah tanpa shalat dan tidak ada shalat tanpa waktu. Dalam alquran telah dijelaskan mengenai dasar penentuan awal waktu subuh dalam surat Al-baqarah ayat 187. Perbedaan penafsiran mengenai awal waktu tersebut muncul lantaran perbedaan penafsiran kata senja. Senja matahari sangat khas penafsirannya. ${ }^{18}$ Susiknan Azhari dalam bukunya yang berjudul Ensiklopedia Hisab Rukyat mengatakan bahwa, secara astronomi fajar dibagi menjadi dua macam, yaitu fajar waktu pagi dan fajar pada saat senja. Fajar waktu pagi dimulai sejak pusat bulatan matahari berada pada posisi 18 derajat di bawah ufuk sampai saat matahari terbit. Sementara itu fajar waktu senja dimulai sejak matahari terbenam sampai pusat bulatan matahari berada pada posisi 18 derajat dibawah ufuk. ${ }^{19}$

Berikut tabel fajar beserta ketinggiannya pada saat berada matahari dibawah ufuk:

17 Sudarmadi Putra, 'Fajar Shadiq dalam Perspektif Astronomi”, Makalah (Semarang: UIN Walisongo, 2017), 9

18 Ibid., 11

19 Unggul, "Problematika Awal Waktu Subuh Antara Fikih dan Astronomi”, 93 


\begin{tabular}{|l|l|l|l|}
\hline No & Awal fajar & Tinggi matahari $\left(^{(}\right)$ & $\begin{array}{l}\text { Intensitas } \\
(\mathrm{LUX})^{20}\end{array}$ \\
\hline 1 & Fajar Sipil & Minus 60 & 6 \\
\hline 2 & Fajar Nautika & Minus $12^{0}$ & 0,06 \\
\hline 3 & $\begin{array}{l}\text { Fajar } \\
\text { Astronomi }\end{array}$ & Minus $18^{0}$ & 0,0006 \\
\hline
\end{tabular}

\section{Warna-warna Fajar}

\section{a Putih Membentang}

Allah berfirman yang artinya "Dan makan minumlah hingga terang bagimu benang putih dan benang hitam, yaitu fajar kemudian sempurnakanlah puasa itu sampai (datang) malam,"

Nabi menafsiri ayat tersebut dengan bersabda :

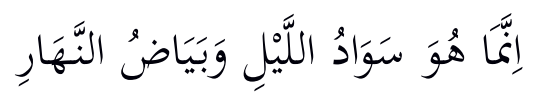

"Sesungguhynya ia adalah gelapnya malam dan putihnya (cahaya) siang." (H.R Bukhari dan Muslim dari Adiy Ibn Hatim) ${ }^{21}$

Jadi benang putih adalah putihnya siang bukan sekedar cahaya siang. Sifat dari putihnya cahaya siang tersebut adalah menyebar memenuhi langit, putih dan cahayanya memenuhi jalan-jalan. Imam Muhammad Ibn Idris asy-syafi'i (204 H) berkata:

" fajar itu ada dua: yang pertama kecil, panjang, meninggi di langit di tengah lintasan. Yang demikian itu tidak menghalalkan shalat dan tidak mengharamkan makan atas orang yang berpuasa. Fajar yang kedua, lebar, putih, bersinar, membentang diufuk, yang demikian ini menghalalkan shalat dan mengharamkan makan bagi yang ingin berpuasa".

${ }^{20}$ Intensitas (LUX) merupakan total cahaya yang terlihat dari pencahayaan sebagai ukuran intensitas pada suatu permukaan

21 Abu Hamid al-Gharnati $(565 \mathrm{H})$, al-Mu'rib'an Ba'dh 'Ajaib al-Maghrib, dikutip oleh Syaikh Umar al-Hadusy dalam Takhrijnya terhadap kitab Syaikh Taqiyuddin alHilali. 
b Merah membentang (putih kekuningan atau kemerah-merahan membentang)

Rasulullah Saw bersabda :

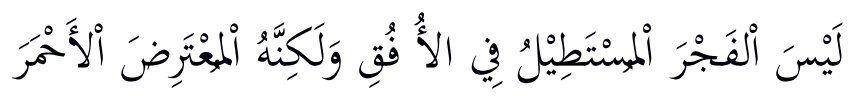

"Bukanlah fajar itu cahaya yang meninggi di ufuk, akan tetapi yang membentang berwarna merah (fajar putih kemerah-merahan)." 22

Mengenai adanya warna merah pada awal fajar shadiq ini telah masyhur di kalangan salaf shalih. Diantara salaf shalif dan para ulama yang menerangkan adanya warna merah di awal fajar shadiq salah satunya ialah Abu Uwanah dalam Mustakhraj-nya atas Shahih Muslim (1/309) berkata :

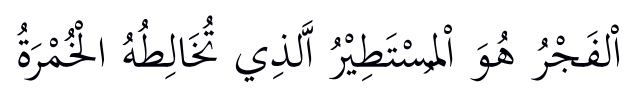

"fajar adalah yang menyebar (di ufuk) yang bercampur merah"

c Biru membentang

Belum dapat ditemui dalam Nushus Shar'iyyah penyebutan warna biru pada awal fajar shadiq, namun hal itu disebut oleh penyair kondang zaman Abbasi (205-284 H/ 821-898 M) dalam bait syair nya:

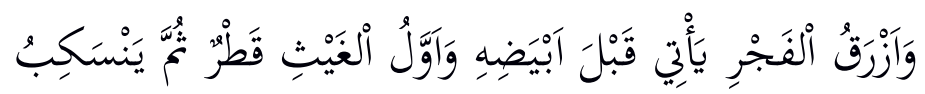

"birunya fajar datang sebelum putihnya, pertamanya hujan adalah tetsan kemudian dicurahkan."

Warna biru fajar ada dua bagian:

a Meninggi kemudian setelah itu redup, gelap kembali maka ini adalah sifat fajar kadzib. Telah banyak keterangan dari para ulama bahwa itu adalah fajar kadzib

${ }^{22}$ HR. Ahmad, dari qais ibn Thalaq dari ayahnya. Hadits hasan, lihat takhrijnya oleh syaikh Abdul Fadl Umar ibn Mas'ud al-Hadusy di kitab Bayan al-fajr as-Shidiq. 
b Membentang ke arah utara dan ke selatan. Membentang ke utara dan selatan adalah sifat fajar shadiq, akan tetapi ada keterangan yang mengatakan bahwa selain membentang warnanya adalah putih atau merah.

Sifat-sifat Fajar (Waktu gholas dan isfar ) Serta Kedudukan Matahari Pada Awal Waktu Subuh

Waktu ghalas dan isfar merupakan waktu awal fajar shadiq. Waktu gholas merupakan waktu malam terakhir (suasana gelap sisa waktu malam), sedang Isfar adalah suasana ketika sudah terang. Waktu subuh adalah sejak terbit fajar shidiq sampai waktu terbit matahari. Fajar shidiq dalam ilmu astronomi dikenal sebagai astronomical twilight (fajar astronomi), cahaya ini mulai muncul diufuk timur menjelang terbit matahari pada saat matahari berada pada sekitar $18^{0}$ dibawah ufuk dengan jarak zenith matahari $108^{\circ}$. Pendapat lain menyatakan bahwa terbitnya fajar shidiq dimulai pada saat matahari $20^{\circ}$ dibawah ufuk atau jarak zenith 110 derajat. Di Indonesia pada umumnya shalat Subuh dimulai pada saat matahari $20^{0}$ dibawah ufuk hakiki (tru horizon). ${ }^{23}$

\section{Analisis Fikih dan Astronomi Putusan Musyawarah Nasional (Munas) Majelis Tarjih Muhammadiyah Ke-31 Mengenai Waktu Subuh}

\section{Analisis Fikih}

Awal fajar/awal waktu subuh dalam fikih adalah ketika munculnya fajar shadiq (garis putih memanjang) di ufuk timur.. Dari penjelasan para ulama fikih (fukaha) khusunya dikalangan empat madzab terkait dengan permulaan waktu shalat subuh, dapat ditarik kesimpulan para ulama sepakat tentang permulaan waktu subuh

${ }^{23} \mathrm{Hal}$ ini bisa dilihat dari pendapat ahli ilmu falak terkemuka di Indonesia yaitu Saadoeddin Djambek yang disebut-sebut oleh banyak kalangan sebagai mujaddid al hisab di Indonsia. Beliau menyatakan bahwa waktu subuh dimulai dengan tampaknya fajar di bawah ufuk sebelah timur dan berakhir dengan terbitnya matahari. Menurut beliau tampaknya fajar pada waktu subuh pada ketinggian matahri sebesar $20^{\circ}$ dibawah ufuk. 
yaitu sejak terbit fajar shadiq sampai menjelang terbitnya matahari, meskipun masalah kapan datangnya fajar shadiq sampai sekarang masih menjadi perdebatan dikalangan fukoha. Terlebih lagi ditemukan banyak argumen yang menjelaskan mengenai keutamaan shalat diawal waktu. Dalam kalangan pendapat madzab Hanafi waktu shalat subuh yang paling afdhal (utama) adalah pada saat pagi atau saat sinar matahari mulai tampak. Sayyid Sabiq (Fikih sunnah: 72-73) menjelaskan bahwa ada hadits yang memperkuat untuk memerintahkan shalat subuh dalam penggalan hadits Rafi' bin Hadid pada waktu pagi sebagai berikut :

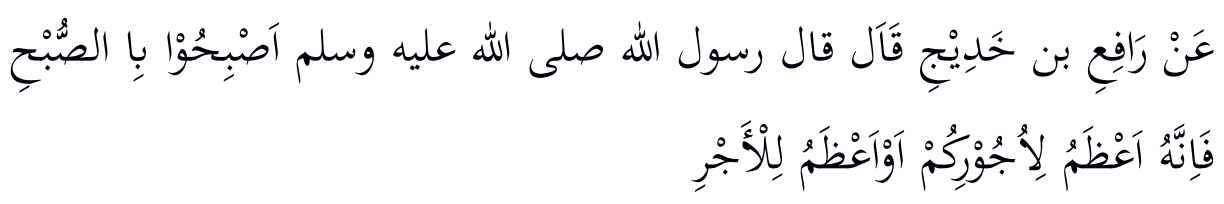

“Dari Rafi'bin Khadij dia berkata. Rasulullah bersabda:

Laksanakanlah shalat subuh ketika pagi telah tiba karena itu lebih

besar pahalanya bagi kalian, atau lebih besar pahalanya" (HR at-

Tirmidzi dan lainnya)

Maksud penggalan kalimat diatas adalah shalat subuh sejak terbitnya fajar sampai tibanya waktu isfar, dimana waktu isfar itu merupakan waktu menjelang terbitnya matahari (menjelang akhir waktu subuh) bukan awal waktu untuk memulai shalat subuh. sehingga kalimat tersebut juga bermakna memperpanjang bacaan (surat) sebagaimana yang dilakukan oleh Rasul dengan memebaca 60 sampai 100 ayat yang dimulai sejak terbit fajar hingga tibanya waktu isfar. Terlebih lagi ditemukan beberapa hadits yang menjelaskan tentang keutamaan shalat diawal waktu saat Nabi saw, Abu Bakar, Umar dan Utsman melaksanakan shalat subuh saat gelap (taghlis), kemudian dimaknai dengan awal fajar shadiq karena setelah itu hari mulai terang (berbeda dengan fajar kadzib yakni hari menjadi gelap kembali). Sementara mafzab maliki membagi waktu shalat subuh menjadi dua macam yaitu waktu ihtiyari (sejak terbit fakar shadiq sampai waktu isfar (waktu cerah sebelum terbit matahari) dan waktu 
dharurat yaitu setelah waktu isfar sampai terbitnya matahari (AlFiqh ‘ala Madzahib al-Arba'ah: 185).

Dalam hadits dari Aisyah yang diriwayatkan oleh al-Bukhori dalam praktiknya Rasulullah Saw shalat subuh ketika ghalas dan pernah pula saat isfar (sudah terang). Namun menurut ahli fikih hadits aisyah tersebut difahami sebagai kebolehan, dan tidak berati nabi selalu mengerjakan seperti itu, sehingga kelompok ini (Muhammadiyah) mengambil kesimpulan bahwa tatkala terbit sinar subuh itu lebih afdhal dibandingkan ketika masih gelap untuk melaksanakan sholat subuh. ${ }^{24}$

\section{$2 \quad$ Analisis Astronomi}

Merujuk pada dalil-dalil mengenai shlat subuh, awal waktu subuh dimulai sejak terbit fajar. Sedangkan dalam astronomi awal subuh dimulai saat mulai surutnya cahaya bintang-bintang dilangit, disebabkan oleh pengaruh sinar matahari yang datang dilangit bagian timur, yang menandakan adanya perubahan dari gelap ke terang. Secara astronomi Departemen Agama menetapkan tinggi matahari pada awal subuh adalah -20 , sedangakn muhammadiyah dalam putusan munasnya menggunakan -18 derajat. Hal ini juga dikemukakan oleh beberapa organisasi dunia dan ahli falak Indonesia menetapkan kriteria yang berbeda. Untuk lebih jelasnya dapat dilihat pada tabel berikut :

\begin{tabular}{|l|l|l|}
\hline No & Ahli falak & Posisi Matahari (0) \\
\hline 1 & Saadoe'ddin Djambek & -20 \\
\hline 2 & KH. Zubair Umar al-Jailani & -18 \\
\hline 3 & Muhammad Ma'sum bin Ali & -19 \\
\hline 4 & Abdur Rachim & -20 \\
\hline 5 & Noor Ahmad SS & -20 \\
\hline
\end{tabular}

24 Ruslan fariadi, waktu subuh perspektif hadits dan madzab, suara muhammadiyah dalam http://suaramuhammadiyah.id/2021/05/17/waktu-subuh-perspektif-haditsdan-madzab/?nv4dietuy=yamp 


\begin{tabular}{|l|l|l|}
\hline 6 & KH. Slamet Hambali & $\begin{array}{l}-19+\mathrm{h} \text { terbit/ } \\
\text { trbenam }\end{array}$ \\
\hline 7 & Thomas Djamaluddin & -18 \\
\hline 8 & Muhyidin Khazin & -20 \\
\hline
\end{tabular}

Selanjutnya pada tabel diatas secara astronomi menunjukkan kriteria posisi matahari awal subuh yang digunakan oleh Indonesia saat ini adalah -20, namun oleh Muhammadiyah dikoreksi menjadi 18 derajat, berarti terdapat selisih 2 derajat dibandingkan dengan ketentuan yang ada di Kementrian Agama. Khusus kriteria yang dikemukakan oleh ahli falak Indonesia, pada umunya berargumen dengan fenomena fajar astronomi, dimana ketika posisi matahari berada sekitar $18^{\circ}$ atau $20^{\circ}$ saat itu cahaya bintang mulai redup karena mulai munculnya hamburan cahaya matahari, yang kemudian didefinisikan sebagai akhir malam atau awal waktu subuh.

Alasan astronomi lainnya (pengambilan kriteria 18-20 derajat di bawah ufuk sebagaimana diterapkan di Indonesia yang berbeda dengan beberapa negara lainnya, karena atmosfer indonesia yang berada di bawah equator relatif lebih tebal dari lintang tinggi misalnya, tebal troposfer di lintang tinggi sekitar $10 \mathrm{~km}$, diwilayah ekuator sekitar $17 \mathrm{~km}$. Dengan kata lain karena atmosfer di Indonesia lebih tebal maka untuk menghamburan cahaya yang lebih tinggi posisi matahari berada paling bawah, sehingga jelas akan berebeda dengan negara yang posisinya jauh dari ekuator. Jika mengambil posisi matahari lebih kecil (misal 150) dalam kondisi seperti di Indonesia, berarti hari telah mulai terang. Jika ini yang terjadi maka untuk shalat subuh relatif tidak bermasalah karena ada pilihan waktu, tapi bagi orang yang akan berpuasa, karena awal waktu Subuh sering dijadikan patokan mulai puasanya dan ia masih makan sahur, maka puasanya menjadi batal. 


\section{Bentuk-bentuk Koreksi Waktu Subuh Majelis Tarjih Muhammadiyah dan Implikasinya}

Secara astronomi Departemen Agama menetapkan tinggi matahari pada awal subuh adalah $-20^{0}$ dibawah ufuk. Berdasarkan pemaparan sebelumnya lembaga Majelis Tarjih Muhamaadiyah melalui Keputusan Musyawarah Nasional XXXI Nomor 734/KEP/1.0/B/2021 yang ditanhfid kan pada bulan Maret telah melakukan pembahasan dan pengkajian terhadap waktu subuh di Indonesia, dalam putusannya Majelis Tarjih Muhammadiyah mengklaim waktu subuh Indonesia terlalu dini sehingga menggunakan derajat -20 dinilai kurang akurat.

Putusan Majelis Tarjih Muhammadiyah Nomor 734/KEP/1.0/B/2021 tentang waktu subuh menilai angka untuk ketinggian matahari yang lebih akurat adalah -18 derajat. Hal ini disampaikan oleh pimpinan pusat Muhammadiyah secara resmi pada sidang musyawarah nasional ke 31. Di dalam putusannya pada poin pertama/diktum Kesatu juga terdapat petikan, memutuskan: "mengubah ketinggian matahari awal waktu subuh minus 20 derajat yang selama ini berlaku dan sebagaimana tercantum dalam Himpunan Putusan tarjih 3; menetapkan ketinggian matahari awal subuh yang baru yaitu minus 18 derajat di ufuk bagian timur"25 demikian petikan bunyi surat putusan Majelis Tarjih Muhammadiyah tersebut. Konsekuensi dari hasil putusan ini adalah waktu subuh muhammadiyah mundur 8 menit dari waktu subuh yang telah ditentapkan oleh kementrian agama, atau terdapat selisih 2 derajat, dimana $1^{0}$ setara dengan 4 menit, sehingga misalkan waktu subuh wilayah Indonesia Bagian Barat (WIB) menunjukkan pukul 04:15 WIB, maka awal waktu subuh Muhammadiyah mundur 8 menit menjadi 04: 23 WIB.

Putusan Majelis Tarjih Muhamadiyah ini disampaikan untuk seluruh umat islam, dalam isi putusan pada diktum ketiga Muhammadiyah mengintruksikan disemua tingkatan khusunya

25 Putusan Tanfidz Hasil Munas tarjih Muhammadiyah No. 
Majelis Tarjih dan Tajdid untuk mensosialisaikan keputusan ini kepada umat islam dan berbagai pihak sebagai tuntunan dalam melaksanakan ibadah, namun mulai diterapkan dan dilaksanakan secara resmi dan menyeluruh untuk warga Muhammadiyah sendiri sejak ditetapkan putusan ini pada tanggal 20 Maret 2021. Berikut tabel lembaga falak Muhammadiyah beserta nilai ketinggian matahari subuh berdasarkan hasil observasinya berdasarkan hasil putusan munas Majelis Tarjih Muhammadiyah no. 734/KEP/1.0/B/2021:

\begin{tabular}{|c|c|c|}
\hline No & Lembaga Falak & Hasil Observasi \\
\hline 1 & $\begin{array}{l}\text { Obsrvatorium Ilmu } \\
\text { Falak (OIF) } \\
\text { Universitas } \\
\text { Muhammadiyah } \\
\text { Sumatera Utara } \\
\text { (UMSU) }\end{array}$ & $\begin{array}{l}\text { OIF UMSU menggunakan alat Sky } \\
\text { Quality Meter (SQM). Pengambilan } \\
\text { data dilakukan di Kota Medan, Pantai } \\
\text { Romantis (Kabupaten Deli Serdang) } \\
\text { dan Barus (Kabupaten Tapanuli } \\
\text { Tengah). dengan menggunakan } \\
\text { metode Moving, SQM diarahkan ke } \\
0^{0}, 30^{0}, 45^{0} \text {, dan } 90^{0} \text { (zenit) } \\
\text { menyimpulkan bahwa polusi cahaya } \\
\text { berpengaruh terhadap ketinggian } \\
\text { matahari sebagai penentu awal waktu } \\
\text { subuh, selain itu tinggi matahari yang } \\
\text { terendah yaitu } 16,48^{0} \text { untuk data SQM } \\
\text { yang mengarah pada Zenit. }\end{array}$ \\
\hline 2 & $\begin{array}{lr}\text { Pusat } & \text { Studi } \\
\text { Astronomi } & \\
\text { (Pastron) } & \text { yang } \\
\text { berada } & \text { di } \\
\text { Universitas } & \text { Ahmad } \\
\text { Dahlan (UAD) }\end{array}$ & $\begin{array}{l}\text { Patron UAD menggunakan SQM } \\
\text { yang diarahkan ke zenit. } \\
\text { Pengambilan data dilakukan di } \\
\begin{array}{l}\text { Kabupaten Bantul, Kota Yogyakarta, } \\
\text { Kabupaten Kulon Progo, dan } \\
\text { kabupaten } \\
\text { menggunakan Moving Average }\end{array}\end{array}$ \\
\hline
\end{tabular}




\begin{tabular}{|c|c|c|}
\hline & & $\begin{array}{l}\text { untuk mengolah data SQM. } \\
\text { Kesimpulannya nilai } \\
\text { Kecerahan Langit (TKL) dipengaruhi } \\
\text { oleh fase bulan selain adanya polusi } \\
\text { cahaya. Hal ini mempengaruhi nilai } \\
\text { tinggi matahari sebagai awal waktu } \\
\text { subuh, semakin tinggi polusi awal } \\
\text { waktu subuh yang diperoleh dari } \\
\text { pengolahan data menjadi lebih siang } \\
\text { daripada waktu dengan } \\
\text { menggunakan } \\
\text { ketinggian matahari }-20^{\circ} \text {. Tinggi } \\
\text { matahari yang terendah yang berhasil } \\
\text { diukur yaitu }-15,75^{\circ} \text {. }\end{array}$ \\
\hline 3 & $\begin{array}{l}\text { Islamic Science } \\
\text { Research Network } \\
\text { (ISRN) Universitas } \\
\text { Muhamadiyah } \\
\text { Prof. Dr. Hamka } \\
\text { (UHAMKA) }\end{array}$ & $\begin{array}{l}\text { ISRN UHAMKA menggunakan SQM, } \\
\text { kamera DLSR, kamera All-Sky, } \\
\text { Kamera smartphone dan kamera } \\
\text { drone. Pengambilan data dilakukan } \\
\text { di beberapa daerah (Depok, Bogor, } \\
\text { Bekasi, Tangerang, DKI Jakarta, } \\
\text { Cirbon, Gunungkidul, Labuanbajo, } \\
\text { Bitung, Balikpapan, Manokwari) dan } \\
\text { luar negeri (Inggris, Amrika Serikat, } \\
\text { Malasyia, Mesir, Turki, dan Saudi } \\
\text { Arabia. ISRN menyimpulkan dari } 750 \\
\text { hari data subuh (data terbit fajar) di } \\
\text { berbagai daerah di dunia beragam } \\
\text { yaitu }-18,4^{0},-18^{0},-17^{0},-16^{0},-15^{0},-14^{0},- \\
13^{0},-12^{0},-11^{0},-10^{0},-9^{0},-8^{0},-7^{0} \text {. }\end{array}$ \\
\hline
\end{tabular}




\section{KESIMPULAN}

Berdasarkan dari penjelasan penulis yang telah disampaikan, waktu subuh Majelis Tarjih Muhammadiyah dalam putusan munasnya berdasarkan kajian fikih masih menjadi persoalan. Awal waktu subuh dalam fikih ditandai dengan munculnya fajar shadiq diufuk bagian timur, namun kapan waktu fajar itu muncul masih menjadi perbincangan dikalangan fukoha, terlebih dalam putusan munas tersebut tidak dijelaskan bagaimana ciri-ciri fajar menurut organisasi Muhammadiyah, waktu subuh menurut beberapa fukoha dapat terjadi ketika waktu ghalas ataupun ketika waktu isfar, karena masing-masing memiliki dasar , hanya saja berdasarkan beberapa observasi yang dilakukan oleh lembaga falak Muhammadiyah yang masing-masing lembaga tersebut menghasilkan angka ketinggian matahari yang lebih kecil dan akhirnya menetapkan angka -18 untuk kemunculan fajar. Waktu awal subuh/ fajar dalam secara astronomi ditandai dengan meredupnya cahaya bintang-bintang di ufuk timur. Yaitu sesuai pendapat mayoritas ulama yakni berkisar 18 derajat sampai 20 derajat dibawah ufuk. Namun secara astronomi untuk shalat subuh relatif tidak bermasalah karena ada pilihan waktu, tapi bagi orang yang akan berpuasa, karena awal waktu Subuh sering dijadikan patokan mulai puasanya dan ia masih makan sahur, maka puasanya menjadi batal.

\section{DAFTAR PUSTAKA}

Abu Bakar Al-Baihaqy, Ahmad bin Husain bin Ali bin Musa. Sunan al-Baihaqy Al-Kubra, Makkah al-Mukarromah: Maktabah Dar al-Baz, 1994.

Al-Amirul Yamani Al-shin'ani, Al-imam Muhammad bin Ismail Subulus salam sarkh bulughul maram jilid 1 (Bairut: Dar AlFikr) terjm. Al-Albani dalam as-Shahihah no. 22 shahih al-jami: 4278. 
Bashori, Agus Hasan dan Al-Faiz, M. Syu'aib. Waktu Subuh Secara Syar'i, Astronomi dan Empiris. Malang: Yayasan Bina AlMujtama', 2021

Butar, Arwin Juli Rahhmadi. Fajar \& Syafak dalam Kesarjanaan Astronom Muslim dan Ulama Nusantara.Yogyakarta: LKIS, 2018.

Fariadi, Ruslan. waktu subuh perspektif hadits dan madzab, suara muhammadiyah dalam website http://suaramuhammadiyah.id/2021/05/17/waktu-subuhperspektif-hadits-dan-madzab/?nv4dietuy=yamp, diakses pada tanggal 18 Agustus 2021

Kementrian Agama. Al-quran dan Terjemahan. Bandung: PT Sygma Examedia Arkanleema, 2019.

Munfarida, Imroatul. "Problematika dan Solusi tentang Penentuan Waktu Shalat dan Puasa di Daerah Abnormal (Kutub)" Journal Al-Syakhsiyyah Journal of Law and Family Studies, Juni, 2021.

Putra, Sudarmadi. 'Fajar Shadiq dalam Perspektif Astronomi", Semarang: UIN Walisongo, 2017.

Supriatna, Encup. Hisab Rukyat $\mathcal{E}$ Implikasinya.Bandung: Refika Aditama, 2007.

Suryo Adi, Unggul. “Problematika Awal Waktu Subuh Antara Fikih dan Astronomi" Al-Afaq: Desember 2020.

Putusan Tanfidz Hasil Munas tarjih Muhammadiyah No. 734/KEP/1.0/B/2021 